\title{
Znaczenie humanistyki dla kształtowania realistycznych relacji człowieka do przyrody
}

\author{
Ryszard F. Sadowski \\ Instytut Ekologii i Bioetyki, Wydział Filozofii Chrześcijańskiej \\ Uniwersytet Kardynała Stefana Wyszyńskiego w Warszawie, ul. Wóycickiego 1/3, 01-938 Warszawa \\ r.sadowski@uksw.edu.pl
}

\begin{abstract}
Streszczenie
Wraz z narastaniem kryzysu ekologicznego mamy do czynienia z coraz to lepszym jego rozpoznaniem. 0 ile początkowo analizą przyczyn i skutków kryzysu oraz wypracowywaniem strategii jego przezwyciężania zajmowali się reprezentanci nauk przyrodniczych i technicznych, o tyle obecnie dołączyli do nich humaniści, artyści, ludzie kultury i przywódcy religijni. Włączenie się humanistów pozwoliło na lepsze rozpoznanie natury kryzysu ekologicznego, a co za tym idzie - na wypracowanie bardziej adekwatnej strategii jego przezwyciężenia. Na szczególną uwagę zasługuje wkład światowych religii w kształtowanie realistycznej relacji człowieka do przyrody. Artykuł ten ukazuje postępującą humanizację refleksji ekologicznej i przywołuje przykłady zaangażowania przedstawicieli różnych tradycji religijnych na rzecz ochrony lasów.
\end{abstract}

\section{Słowa kluczowe}

ekologia humanistyczna, filozofia środowiskowa, religia i ekologia, sztuki Ziemi, las

\section{Wstęp}

Refleksja nad współczesnym kryzysem ekologicznym ma miejsce od wielu dekad. O ile początkowo była ona zdominowana przez przedstawicieli nauk przyrodniczych, technicznych, ekonomicznych i prawnych, o tyle począwszy od lat 6o. XX wieku stale wzrasta zaangażowanie w tę refleksję przedstawicieli różnych dyscyplin humanistycznych. Począwszy od filozofów, antropologów i etyków, poprzez estetyków i artystów, aż po religiologów i teologów reprezentujących wszystkie największe tradycje religijne świata.

Zaangażowanie humanistów w debatę środowiskową umożliwiło bardziej subtelne rozpoznanie natury kryzysu ekologicznego, a co za tym idzie - wypracowanie bardziej adekwatnych odpowiedzi na ten kryzys. Humaniści pomogli dostrzec kulturowe przyczyny kryzysu środowiskowego. Wiele wskazuje bowiem na to, że jest on konsekwencją zmiany, jaka dokonała się w postrzeganiu świata przyrody wraz z rozwojem cywilizacyjnym. Humaniści wskazali na wpływ, jaki wywarło to zjawisko na stosunek człowieka do świata przyrody. Stosunek ten zmieniał się, począwszy od traktowania przyrody przez człowieka w starożytności jako niezmiennej, potężnej, groźnej i niezwyciężonej, poprzez traktowanie jej 
w nowożytności jako możliwej do gruntownego poznania i opanowania, aż po całkowite zawładnięcie nią dzięki współczesnemu postępowi naukowo-technicznemu.

Obecnie coraz lepiej zdajemy sobie sprawę, że ludzkie zwycięstwo nad przyrodą okazuje się tylko pozornym sukcesem, ponieważ jej pokonanie nieodłącznie wiąże się z klęską człowieka, a być może nawet z całkowitą zagładą życia na Ziemi. Stąd refleksja humanistyczna nad kryzysem ekologicznym skłania do podejmowania prób znalezienia rozsądnego kompromisu pomiędzy cywilizacyjnymi potrzebami człowieka, a możliwościami przyrody w realizacji tych potrzeb. Tylko osiągnięcie realistycznego kompromisu daje nadzieję na pomyślną, trwałą i stabilną przyszłość człowieka i pozostałych członków ziemskiej wspólnoty życia.

Współczesne analizy kryzysu środowiskowego prowadzone przez przedstawicieli nauk przyrodniczych, ścisłych, społecznych, technicznych i humanistycznych zgodnie wskazują na potrzebę instytucjonalnego zaangażowania religii $\mathrm{w}$ walkę $\mathrm{z}$ narastającym kryzysem środowiskowym oraz na wykorzystanie w tej walce argumentacji religijno-moralnej. Religie posiadają bowiem niezwykłe „ekologiczne" atuty, które mogą znacząco wpływać na stosunek do przyrody oraz na styl życia swych wyznawców (Gardner 2003: 154). Wydaje się więc, że przedstawiciele humanistyki tacy jak religiolodzy i teolodzy są nie tylko niezbędnym, ale wręcz koniecznym partnerem w kształtowaniu realistycznej postawy człowieka względem świata przyrody. Odwołują się oni bowiem do różnych tradycji religijnych, które dysponują zdolnością kształtowania codziennych postaw swych wyznawców, czego nie udało się skutecznie osiągnąć ani naukowcom publikującym wyniki swych badań, ani prawodawcom implementującym coraz to bardziej restrykcyjne akty prawne.

\section{Postępująca humanizacja refleksji nad kryzysem ekologicznym}

Przez całe tysiąclecia przyroda jawiła się człowiekowi jako pożyteczna, piękna i tajemnicza, ale jednocześnie potężna, groźna i niepokonana. Wraz z rozwojem cywilizacyjnym, a zwłaszcza dzięki zdobyczom rewolucji naukowo-technicznej, ingerencja człowieka w świat przyrody stała się możliwa na skalę niespotykaną nigdy wcześniej w historii świata. W konsekwencji zakres i tempo zmian zachodzących w świecie przyrody spowodowały negatywne skutki środowiskowe na skalę globalną i dotkliwie wpłynęły na jakość życia znacznej części ludzkiej populacji.

Doświadczenie dramatycznych skutków kryzysu ekologicznego stało się przyczyną nowego spojrzenia na przyrodę. Człowiek zdał sobie bowiem sprawę z tego, że nie jest ona tak potężna i niezwyciężona, jak wcześniej przypuszczał. Świadomość ta dotarła do światowej opinii publicznej w latach 6o. ubiegłego wieku. Dobrze ilustruje to wypowiedź sekretarza generalnego ONZ U Thanta, który 9 maja 1969 r. stwierdził, że ludzkość znalazła się w dramatycznym położeniu i w jego ocenie pozostało nie więcej niż dziesięć lat na podjęcie radykalnych działań zmierzających do powstrzymania kryzysu ekologicznego. Zdaniem U Thanta zaniechanie tych działań doprowadzi do tego, że opanowanie narastających problemów nie będzie już możliwe (Meadows et al. 1973: 37).

Duży wpływ na zaniepokojenie światowej opinii publicznej narastaniem kryzysu ekologicznego miały m.in.: wspomniane wystąpienie sekretarza generalnego ONZ, ogłoszony przez niego raport „Problemy ludzkiego środowiska" (1969), wydana w wielu milionach egzemplarzy głośna książka Jaya W. Forrestera „World Dynamics” (1971) oraz raporty Klubu Rzymskiego „Granice wzrostu” (1972) i „Ludzkość w punkcie zwrotnym" (1974). Zaniepokojenie to pogłębiło się jeszcze bardziej wraz z wybuchem kryzysu paliwowego na początku lat 70. XX wieku.

Niezwykle ważną rolę w budzeniu powszechnej świadomości ekologicznej oraz w zmianie postrzegania kryzysu ekologicznego odegrała książka Rachel Carson „Silent 
Spring" (1962). Po latach Edward O. Wilson stwierdził nawet, że wywarła ona elektryzujący wpływ na opinię publiczną i stała się inspiracją dla wielu organizacji ekologicznych (Wilson 2002: 357). Zaś Bruno Fritsch wyraził opinię, że książka Carson była inspiracją humanistycznego nurtu ekologicznego, który zapoczątkował nowy paradygmat ujmowania kryzysu ekologicznego (Fritsch 1990: 9-17).

Doświadczenie skutków kryzysu zainspirowało wielu uczonych do podjęcia badań w celu określenia bezpośrednich jego przyczyn oraz wskazania dróg jego rozwiązania. Politycy podjęli próby wypracowania rozsądnego kompromisu w celu zmniejszenia szkodliwego oddziaływania człowieka na środowisko. Zaś zaniepokojeni ludzie, zwłaszcza obywatele państw zachodnich, zainicjowali powstanie wielu organizacji ekologicznych, których celem było z jednej strony podjęcie konkretnych działań na rzecz ochrony środowiska, z drugiej zaś wywieranie presji na polityków, by podjęli realne działania na rzecz poprawy kondycji Ziemi. Przełom lat 6o. i 70. ubiegłego wieku jest więc często określany jako tzw. przebudzenie ekologiczne społeczeństw Zachodu.

O ile początkowo w badania nad kryzysem środowiskowym zaangażowali się przede wszystkim przedstawiciele nauk przyrodniczych, technicznych i ekonomicznych przy współudziale prawników i polityków, o tyle z czasem dołączyli do nich także humaniści. Szybko bowiem zdano sobie sprawę z tego, że natura kryzysu środowiskowego jest tak bardzo złożona, że nie da się go przezwyciężyć jedynie za pomocą środków technicznych oraz uregulowań prawnych. Już na przełomie lat 60. i 70. pojawiły się pierwsze filozoficzne analizy kryzysu ekologicznego, które zainspirowały liczne środowiska filozoficzne w Europie i Ameryce. Ożywione zainteresowanie filozofów problemami środowiskowymi przyczyniło się zaś do powstania filozofii ekologicznej i etyki środowiskowej (Tyburski 2006: 8). Obecnie filozofia środowiskowa jest już dobrze ukształtowanym działem filozofii, w którym pojawiło się wiele oryginalnych nurtów i szkół (Sadowski 2015: 33-53).

Interdyscyplinarne badania kryzysu środowiskowego pozwoliły lepiej rozpoznać jego złożoność i przyczyniły się do zainteresowania tą tematyką coraz to nowych przedstawicieli różnych działów nauk humanistycznych. W wyniku ekologicznego ożywienia humanistów powstała m.in. estetyka ekologiczna, która znajduje wyraz artystyczny w twórczości wielu działów sztuki. Twórczość ta koncentruje się na ukazywaniu piękna przyrody i podkreślaniu znaczenia kontaktu człowieka z przyrodą dla jego harmonijnego rozwoju (Bonenberg 200o). Z czasem artystyczne wyrazy zachwytu nad przyrodą zaczęto określać jako „sztuki Ziemi”, bądź „sztuki życia” (ang. Land art, Earth art, environmental art, Earthworks). Ożywione zainteresowanie kwestią ekologiczną obserwujemy także w kulturze masowej. Oddziaływanie na powszechną opinię społeczną w kwestii ekologicznej dobrze ilustrują takie głośne produkcje hollywoodzkie, jak choćby „Wodny Świat” (1994), „Pojutrze” (2004), „2012” (2009), „Avatar” (2009) i „Geostorm" (2017).

Kolejnym etapem zaangażowania humanistyki w kwestię środowiskową jest włączenie się religiologów i teologów reprezentujących wiele różnych tradycji religijnych. Znaczenie zaangażowania przedstawicieli nauk teologicznych w wypracowanie wszechstronnej strategii na rzecz przeciwdziałania kryzysowi ekologicznemu zauważają i doceniają reprezentanci pozostałych dyscyplin naukowych oraz politycy (Sadowski 2010: 78-80). Potwierdzeniem tego zaangażowania jest powstanie nowej gałęzi wiedzy określanej jako religion and ecology. Dyscyplina ta rozwija się prężnie w USA, Australii i Europie. Na wielu prestiżowych uczelniach proponowane są kursy licencjackie i magisterskie, a nawet studia doktoranckie ze specjalności religion and ecology (Foltz 2006: 1-4).

\section{Relacja kultury i natury}

Wraz z rozwojem cywilizacyjnym człowiek zaczął coraz lepiej zdawać sobie sprawę 
z tego, że wytworzona przez niego kultura i otaczająca go natura oddziałują na siebie. Świadomość ta miała wpływ na kształt ambiwalentnej relacji człowieka do przyrody. Wprawdzie nie miał on wątpliwości co do swojej przynależności do świata przyrody oraz tego, że jest mu ona niezbędna do życia, ale jednocześnie nieustannie przeciwstawiał się przyrodzie. Zaś stworzona przez niego kultura stanowiła barierę chroniącą go przed naturą i pozwalała mu najpierw „oswajać” przyrodę, by następnie podjąć próby całkowitego zapanowania nad nią.

Refleksja człowieka nad oddziaływaniem natury i kultury ma miejsce od tysięcy lat. Już starożytni Grecy mieli świadomość ich wzajemnego wpływu, byli jednak przekonani, że oddziaływanie natury ma dużo większe znaczenie ze względu na jej nieporównywalnie większą potęgę i dominację nad światem kultury (Moran 2006: 27-28). Wiele wskazuje na to, że pierwszym, który wyraźnie opisał wpływ świata przyrody na człowieka był Tukidydes (46o-395 a.Ch.n.). W „Wojnach peloponeskich” zaproponował on wyjaśnienie stylu życia greckich plemion przy pomocy oddziaływania warunków środowiskowych (Tukidydes 1991: ks. 1, nr 2). Żyjący nieco później Hipokrates (460-377 a.Ch.n.) wskazywał zaś na wpływ różnych rodzajów klimatu na temperament człowieka (Hipokrates 1890: \$23). Myśl tę rozwinął Arystoteles (384-322 a.Ch.n.), który stwierdził, że tylko narody żyjące w klimacie umiarkowanym, jak Grecy, są zdolne do wykształcenia u swych obywateli dwóch najważniejszych dla dominacji w świecie cech: odwagi i twórczej kreatywności (Arystoteles 2006: ks. 7, rozdz. 6, nr 1).

Bazując na tych i im podobnych opiniach, wypracowano koncepcję determinizmu środowiskowego, w myśl którego środowisko ma zasadniczy wpływ na kształt kultury ludu zamieszkującego określony obszar. Jednak na początku XX wieku determinizm środowiskowy utracił swą popularność na rzecz posybilizmu środowiskowego, który głosił, że środowisko stwarza jedynie paletę możliwych dróg rozwoju kultury, spośród których człowiek arbitralnie wybiera jedną możliwość i realizuje ją w praktyce (Simmons 1990: 3-7).

Ze względu na to, że przez tysiąclecia człowiek był przekonany o nieograniczonej potędze i nieskończoności przyrody, jego refleksje na temat oddziaływania natury i kultury zwykle koncentrowały się na wpływie tej pierwszej. Wraz z rozwojem cywilizacji naukowo-technicznej ludzkość coraz wyraźniej uświadamiała sobie własną potęgę i możliwość ingerowania w świat przyrody. Świadomość ta była inspiracją do podjęcia refleksji nad wpływem świata kultury na świat natury. Współcześnie można mówić o szerokiej palecie poglądów na temat wzajemnej relacji kultury i natury. $\mathrm{Z}$ jednej strony mamy do czynienia z radykalnymi stanowiskami, które głoszą dominujący wpływ warunków środowiskowych na kształt kultury, z drugiej zaś spotykamy radykalne stanowiska, które utrzymują, że to świat kultury ostatecznie przesądza o kształcie środowiska życia człowieka. Istnieje też bogate spektrum stanowisk pośrednich, które odrzucając radykalne koncepcje, przypisują odpowiednią rolę we wzajemnym kształtowaniu się zarówno elementom świata kultury, jak i świata natury.

Przedstawiona tu pobieżna analiza ukazuje historyczne tendencje zmian w ujmowaniu wzajemnych relacji natury i kultury. Rozwój cywilizacyjny zupełnie zmienił dotychczasowy układ sił pomiędzy nimi. O ile w historii przyroda była niekwestionowanym liderem tej relacji, o tyle z czasem człowiek ze swą kulturą całkowicie zdominował przyrodę. Można to określić następująco w początkowych stadiach rozwoju ludzkości krucha kultura rozwijała się w ramach potężnej natury i potrzebowała niezbędnego do swego rozwoju wsparcia i obrony przed przyrodą, obecnie mamy zaś do czynienia z sytuacją, kiedy to nadwątlona natura rozwija się w ramach kultury i od człowieka zależy, w jakim zakresie będzie to możliwe. Dziś to właśnie zagrożona natura wymaga ochrony przed ekspansywną kulturą. 
Historyczny etap dominacji natury względem świata kultury opisał Hans Jonas. Jego zdaniem dobrą ilustracją tego etapu relacji natury i kultury jest miasto. $Z$ jednej strony symbolizuje ono lęk człowieka przed przyrodą, z drugiej zaś strony stanowi swego rodzaju enklawę, w której człowiek tworzy kulturę. Tylko w obrębie miejskich murów czuje się on bezpieczny i zdolny do rozwoju właściwego mu świata kultury. Wydaje się natomiast, że symbolem obecnego etapu dominacji kultury mogą być ogrody zoologiczne, parki narodowe i rezerwaty przyrody. Tam bowiem chroniona jest przyroda, która ze względu na władzę, jaką człowiek zyskał nad nią, jest całkowicie zdana na jego łaskę. Jonas zauważa ponadto, że o ile w pierwszym etapie rozwoju cywilizacyjnego człowiek zwolniony był z odpowiedzialności za przyrodę, a przedmiotem jego odpowiedzialności były jedynie relacje międzyludzkie, o tyle na obecnym etapie rozwoju cywilizacji człowiek zmuszony jest podjąć odpowiedzialność za przyrodę, która sama nie może już zatroszczyć się o siebie (Jonas 1995: 25-26).

Szukając odpowiedzi na pytanie o optymalny kształt relacji pomiędzy światem kultury i światem przyrody, można odwołać się do nauk przyrodniczych, które dobrze rozpoznały zjawisko ścisłego współżycia organizmów należących do różnych gatunków. Wydaje się zatem, że terminologia nauk przyrodniczych może pomóc w opisie koegzystencji tak różnych rzeczywistości, jakimi są kultura i natura. Wiele wskazuje na to, że pomocne w tym opisie będą takie pojęcia jak: komensalizm, pasożytnictwo i mutualizm (Łepko 2003: 170-171; Martin, Schwab 2013).

Analizując poszczególne etapy relacji kultury i natury, można stwierdzić, że na etapie wczesnego rozwoju cywilizacji relację świata kultury i świata przyrody najlepiej oddaje termin określany jako komensalizm, tzn. różne gatunki oddziałują na siebie, przy czym jeden gatunek czerpie z tego korzyści, podczas gdy w stosunku do drugiego relacja ta jest neutralna. Wyraźnym beneficjentem relacji kultury i natury na początkowym etapie rozwoju cywilizacji ludzkiej był świat kultury. Świat przyrody podlegał wprawdzie pewnym negatywnym wpływom, były one jednak stosunkowo niegroźne ze względu na niewielką liczebność ludzkiej populacji i ograniczone możliwości techniczne człowieka, a co za tym idzie - niewielką ingerencję w ziemskie środowisko i niezdolność do zakłócenia jego równowagi.

$\mathrm{Na}$ etapie intensywnego rozwoju ludzkiej cywilizacji, a szczególnie w okresie rewolucji naukowo-technicznej, wzajemne relacje świata kultury i świata przyrody najlepiej opisuje termin pasożytnictwo. Termin ten odnosi się do koegzystencji różnych gatunków, w wyniku czego jedne gatunki odnoszą wyraźną korzyść, podczas gdy drugie doświadczają dotkliwych szkód, które niekiedy prowadzą nawet do śmierci wykorzystywanego organizmu. Wydaje się, że na tym etapie cywilizacyjnym można przyrównać człowieka do pasożyta, który czerpiąc z przyrody w sposób nieodpowiedzialny, zaburza jej równowagę i prowadzi do degradacji. Ostatecznie zaś sprowadza na nią niebezpieczeństwo unicestwienia.

Analizując aktualną kondycję ziemskiego ekosystemu i kierunki rozwoju ludzkiej cywilizacji, można przypuszczać, że jeżeli świat kultury ma przetrwać, to wzajemne relacje kultury i natury muszą wejść w trzeci etap. Na tym etapie związek kultury i natury powinien przyjąć formę związku mutualistycznego, tzn. takiego, który podkreśla ścisłe i wzajemne uzależnienie obu elementów oraz fakt, że oba czerpią proporcjonalne korzyści z tego związku. Tylko wzajemnie korzystna relacja świata kultury i świata przyrody daje nadzieję na przetrwanie każdego z tych światów bez poniesienia nieodwracalnych strat. W przeciwnym bowiem razie świat kultury skazany będzie na zagładę, zaś świat przyrody dozna poważnego uszczerbku, tracąc najbardziej rozwinięty gatunek, jakim jest Homo sapiens.

Wydaje się, że nadzieją na wprowadzenie mutualistycznej relacji świata kultury i świata natury jest koncepcja pokoju 
człowieka z przyrodą, wypracowana w ramach praktycznej filozofii przyrody. Podstawą tej koncepcji jest filogenetyczny związek człowieka ze światem przyrody. Tylko uświadomienie człowiekowi, że wywodzi się on z przyrody i jest jej częścią może wpłynąć na odpowiedni jego stosunek do przyrody. Nie chodzi tu jednak o deprecjonowanie człowieka i zrównywanie go z resztą przyrody, ale o wskazanie, że jego wyjątkowe zdolności pociągają za sobą wyjątkowe obowiązki, którym żaden inny gatunek nie jest w stanie podołać. Człowiek jest więc nie tylko częścią przyrody, ale także jej szansą i nadzieją. Tylko on może bowiem wziąć odpowiedzialność za przyrodę (Meyer-Abich 1987: 67; Selmaj-Pomaska 2011: 346).

Koncepcja pokoju człowieka z przyrodą bazuje na prawdzie o przyrodzie i o człowieku, zaś badania na temat relacji człowieka do przyrody jednoznacznie wskazują, że człowiek jako najdoskonalszy element przyrody jest predestynowany do panowania nad nią. Chodzi jednak o to, by wskazać odpowiedni model tego panowania. Należy zatem odejść od absolutystycznej, nieograniczonej władzy człowieka nad przyrodą na rzecz władzy demokratycznej, ograniczonej regulacjami prawnymi. Pokój człowieka z przyrodą powinien więc przyjąć formę niespisanego paktu, w oparciu o który człowiek wraz z prawem do panowania nad przyrodac otrzymuje obowiązek odpowiedzialności za nią (Meyer-Abich 1984: 14; Łepko 2003: 186-187).

Gwarancją utrzymania pokoju człowieka z przyrodą jest przyjęcie realistycznych celów, które $\mathrm{z}$ jednej strony zaspokoją aspiracje człowieka, z drugiej zaś - uwzględnią możliwości przyrody. Interesy człowieka i przyrody powinny być więc przeanalizowane i rozsądnie uzgodnione. Celem tego paktu nie może być nierealistyczny projekt przywrócenia dziewiczej przyrody, uniemożliwi to bowiem zaspokojenie potrzeb człowieka. Celem paktu nie może być także zgoda na aktualny styl życia człowieka, w szybkim tempie doprowadzi on bowiem do degradacji środowiska, aby ostatecznie spowodować całkowite załamanie równowagi ziemskiego ekosystemu. Wydaje się, że rozsądnym kompromisem, który pozwoli zabezpieczyć podstawowe interesy obu stron paktu jest przywrócenie stanu przyrody, jaki miała ona ok. stu lat temu oraz rozsądne ograniczenie konsumpcyjnych potrzeb człowieka. Dochodzenie do tego stanu powinno odbywać się jednak stopniowo, a interesy człowieka i przyrody powinny być wyważone i nie powinno się faworyzować żadnej ze stron tego porozumienia (Selmaj-Pomaska 2011: 350).

Zawarcie pokoju między człowiekiem i przyrodą powinno w efekcie prowadzić do uzgodnienia politycznej i gospodarczej organizacji społeczeństwa industrialnego z porządkiem przyrody (Łepko 1995: 40), zaś konsekwencją zawarcia tego pokoju powinno być wskazanie zasad korzystania z nauki i techniki, by uszanować prawa przysługujące przyrodzie (Meyer-Abich 1988: 82). To z kolei prowadzi to do konieczności wypracowania nowego modelu nauki i nowego modelu gospodarowania na rzecz przyszłych pokoleń (Łepko 1995: 40-41).

\section{Znaczenie religii dla kształtowania realistycznej relacji człowieka do lasu}

Znaczenie religii i ich wkład w przeciwdziałanie kryzysowi ekologicznemu jest obecnie dobrze rozpoznane i opisane w literaturze naukowej. Ekologiczne atuty religii powodują, że stały się one ważnym, a nawet niezbędnym sprzymierzeńcem w walce $\mathrm{z}$ kryzysem ekologicznym (Tucker 2003). Wydaje się, że wszystkie największe światowe religie kształtują wśród swych wyznawców realistyczne relacje do świata przyrody. Znaczy to, że żadna z najbardziej wpływowych religii świata nie promuje „nietykalności” przyrody, żadna nie zachęca też wiernych do dowolnego i nieodpowiedzialnego dysponowania zasobami przyrody. Wszystkie zaś nakłaniają swoich wiernych do poszanowania przyrody bądź to z powodu szacunku do dzieła stworzenia, bądź to ze względu na obecny w przyrodzie 
pierwiastek duchowy. Wszystkie największe religie świata nie pozostawiają też wątpliwości co do prawa człowieka do korzystania z zasobów natury. Zwracają jednak przy tym uwagę na konieczność respektowania jej możliwości w zaspakajaniu potrzeb człowieka i zachęcają do rozsądnego ograniczania tych potrzeb, by nie nadwyrężać zaburzonej równowagi ziemskiego ekosystemu.

Wpływ religii wydaje się szczególnie ważny w kontekście tzw. little conservation. Bogate doświadczenia będące wynikiem realizowanych projektów ekologicznych pokazują, że uzgodnienie little conservation z big conservation znacznie podnosi skuteczność projektów ekologicznych. Synchronizacja zasobów ekonomicznych i nowoczesnych technologii właściwych big conservation ze znajomością kultur społeczności lokalnych i terenów przez nie zamieszkałych właściwych little conservation stwarza podstawy skutecznej ochrony określonych gatunków i całych ekosystemów (Boucher 2011: 59-66).

Istotnym elementem tożsamości każdej społeczności jest jej religia, która wpływa na kulturę tej społeczności we wszystkich jej wymiarach. Szczególnie zaś rzutuje ona na sposób postrzegania świata i człowieka, a w konsekwencji na jego relacje do pozostałych przedstawicieli własnej społeczności i społeczności obcych oraz na relacje człowieka do otaczającego go świata. Wydaje się więc, że religie mogą w znacznym stopniu przyczyniać się do ochrony ekosystemów leśnych. W różnych tradycjach religijnych wpływ ten będzie przebiegał inaczej. Jest on bowiem uwarunkowany odmiennymi koncepcjami świata, człowieka, ich celów oraz modelu relacji człowieka do świata. Zasadniczo jednak religie zawsze prowadzą do poprawy kondycji lasów. Tradycje religijne, które odwołują się do animizmu lub panteizmu w odmienny sposób argumentują na rzecz ochrony drzew niż robi to judaizm, chrześcijaństwo czy islam. Obecnie mamy jednak powszechną zgodę co do pozytywnego zaangażowania wszystkich światowych religie na rzecz ochrony terenów leśnych.
Poniżej przedstawione zostaną wybrane religijne inicjatywy na rzecz ochrony lasów. Będą one ukazywały prośrodowiskową działalność, metody oraz argumentację stosowaną przez instytucje religijne i organizacje ekologiczne o religijnej proweniencji. Analiza zjawiska religijnej troski o kondycję lasów pozwala stwierdzić, że działania te mają dwojaki charakter. Z jednej strony chronią istniejące ekosystemy leśne, z drugiej zaś zmierzają do odbudowy tych ekosystemów na terenach, gdzie uległy one zniszczeniu. Daje się także zaobserwować pewną prawidłowość w zakresie używanej argumentacji. O ile religie Wschodu w trosce o lasy często odwołują się do świętości przyrody i obecnego w niej pierwiastka duchowego, o tyle monoteistyczne religie Zachodu odwołują się najczęściej do konieczności troski o dzieło Stwórcy oraz podkreślają, że działania na rzecz ochrony przyrody są jednocześnie przejawem troski o drugiego człowieka (Sadowski 2015: 157-175).

Wydaje się, że największy wkład we współczesną ochronę lasów wnosi tradycja hinduistyczna. Jej znaczącym wkładem na tym polu są święte gaje, które stały się swego rodzaju rezerwatami bioróżnorodności. Według danych opublikowanych w roku 1998 spośród ogromnej liczby zgłoszonych w Indiach świętych gajów zweryfikowano jedynie 4415 i potwierdzono, że obejmują one 42 tys. ha (Gokhale et al. 1988). Zaś według spisu przeprowadzonego kilka lat później oszacowano przybliżoną liczbę wszystkich świętych gajów na terenie Indii na ok. 100-150 tys. Pokazuje to skalę zjawiska oraz niezwykły wkład hinduizmu w troskę o bioróżnorodność (Sadowski 2012: 17-21). Instytucja świętych gajów jest obecna także w innych religiach Wschodu i w religiach pierwotnych. Szczególnie dużo świętych gajów znajduje się w krajach azjatyckich i afrykańskich, do krajów tych należą m.in. Indie, Chiny, Tajlandia, Indonezja, Japonia oraz Nigeria, Ghana i Kenia (Sadowski 2012: 19).

Ochrona drzew w hinduizmie ma tradycję sięgającą XV wieku, kiedy to powstała grupa religijna Bishnoi Community. Założyciel tej 
wspólnoty - Guru Jambheśvara - wśród zasad będących podstawą jej funkcjonowania wskazał m.in. rygorystyczny zakaz niszczenia drzew i zabijania zwierząt. Potwierdzeniem determinacji Bishnoi w chronieniu lasów jest wydarzenie, które miało miejsce w XVIII wieku, kiedy to 363 członków tej wspólnoty religijnej oddało życie w obronie wycinanych drzew (Jain 2011: 51-77).

Do tradycji tej nawiązuje obecnie Chipko Movement, który odwołuje się do argumentacji religijnej właściwej hinduizmowi (Yaakov 1997). Ruch ten powstał w roku 1973 w ramach protestu przeciwko masowej wycince drzew w regionie Garhwal Himalayas. Społeczność lokalna, doświadczając skutków masowej deforestacji w postaci powodzi, przeciwstawiła się urzędnikom, którzy nie uwzględnili ekologicznych i społecznych konsekwencji wycinki lasów. Skuteczność protestu ośmieliła lokalną społeczność do poczynienia dalszych kroków, które doprowadziły do ogłoszenia przez rząd Indii w 1981 roku piętnastoletniego moratorium na przemysłową wycinkę drzew w regionie Himalajów, by następnie wprowadzić całkowity zakaz wyrębu drzew na wysokości powyżej 1000 m n.p.m. (Sadowski 2013: 11-13).

O ile Chipko Movement zajmuje się ochronią lasów na północy Indii, o tyle na południu powstał w roku 1983 podobny ruch pod nazwą Appiko Movement. Wielkim osiągnięciem Appiko było zainspirowanie opinii publicznej do działań na rzecz ochrony drzew w lesie Kalase-Kudergod, który jest obszarem unikalnym pod względem ekologicznym i istotnym dla stanu środowiska przyrodniczego znacznych obszarów południowych Indii (Sadowski 2013: 13-14).

Inną formę ochrony lasów obserwujemy w muzułmańskiej tradycji religijnej. Szczególnie aktywni w tym względzie są muzułmanie z Indonezji, którzy wydali jak dotąd pięć „fatw ekologicznych”. Fatwa w islamie oznacza nieobligatoryjny nakaz prawny lub oficjalną opinię wystosowaną przez kompetentnych przedstawicieli tej religii $\mathrm{w}$ celu wyjaśnienia i podpowiedzenia wyznawcom islamu właściwych zachowań odnośnie do określonych wymiarów życia społecznego. Islamska Rada Indonezji (ang. Islamic Council of Indonesia) wydała ekologiczne fatwy, w których poinformowano wiernych, że takie działania jak: deforestacja, umyślne podpalenia lasów, wyrąb lasów naturalnych pod plantacje palm jest haram, tzn. zakazane lub grzeszne (Web-01).

Szczególnie głośnym echem odbiła się fatwa wydana w Indonezji w styczniu 2014 i we wrześniu 2016 roku. Wydaje się, że są to pierwsze ekologiczne fatwy, które mówią o kompleksowej ochronie całych ekosystemów. Ta religijna forma oddziaływania na obywateli Indonezji, z których niemal 90\% to muzułmanie, miała na celu zmianę nastawienia opinii publicznej do kwestii środowiskowych, którego nie udało się osiągnąć poprzez nakazy prawa państwowego. Podkreślając znaczenie wydanych fatw, muzułmańscy przywódcy stwierdzili, że „ludzie mogą unikać przestrzegania nakazów rządu, nie są jednak w stanie uniknąć słowa Boga" (Web-02). Należy nadmienić, że ekologiczna fatwa jest czymś nowym w świecie islamu. Ośrodki naukowe z kilku krajów przez dwanaście lat pracowały nad uzasadnieniem wydania tego typu orzeczeń, które zachęcałyby wyznawców islamu do zaniechania lub podejmowania określonych postaw względem środowiska przyrodniczego. Do ośrodków zaangażowanych $\mathrm{w}$ ten projekt należały $\mathrm{m}$.in. Jakarta University, The Centre for Islamic Ecology at Lampeter, University of Wales oraz Al-Azar University in Cairo (Web-03).

Głos w obronie lasów wielokrotnie zabierał także Dalai Lama, duchowy przywódca buddyzmu. Wyrażał on smutek z powodu polityki Chin w stosunku do Tybetu, gdzie w przeciągu kilkudziesięciu lat góry porośnięte niegdyś dorodnymi lasami zostały w znacznej części pozbawione drzew. Dalai Lama stwierdził wręcz, że dziś góry te przypominają łysinę buddyjskich mnichów. W konsekwencji spowodowało to wyginięcie licznych stad zwierząt, utratę piękna krajobrazu oraz trudności lokalnej ludności w zaopatrzeniu w opał. Dalai Lama zauważył 
ponadto, że postępująca deforestacja prowadzi z jednej strony do braku wody, z drugiej zaś - do okresowych powodzi, z powodu których cierpią także znaczne obszary północnych Chin (Web-04).

W obronie lasów głos zabierali także inni przedstawiciele buddyzmu. W ważnym wystąpieniu na temat zmian klimatycznych przypomnieli, że jeśli nie dokonamy gruntownych zmian w pozyskiwaniu i gospodarowaniu energią, a także w przemyśle, transporcie, leśnictwie, rolnictwie oraz nie porzucimy konsumpcyjnego stylu życia, to w przeciągu zaledwie kilku dekad nieodwracalne zmiany klimatu doprowadzą do upadku ludzkiej cywilizacji (Web-05).

W obronie lasów stają także liczne środowiska chrześcijańskie. Przykładowo, amerykańscy prezbiterianie podejmują liczne inicjatywy w celu ograniczenia budowy dróg w amerykańskich parkach narodowych oraz ochrony krajobrazu na obszarach, gdzie ingerencja człowieka jest stosunkowo niewidoczna. Wywierają też presję na rząd USA i inne organizacje krajowe i międzynarodowe m.in. w celu wstrzymania wyrębu starodrzewów, fragmentyzacji obszarów leśnych oraz budowy wielkich tam (Web-o6). Z kolei Zjednoczony Kościół Metodystów podejmuje działania zmierzające do ochrony ekosystemów leśnych. W wydanym w 2008 roku dokumencie zwraca uwagę, że deforestacja prowadzi do erozji gleb, zmniejsza możliwość absorpcji ditlenku węgla, osłabia jakość wody i zmniejsza bioróżnorodność (Web-07).

Symboliczne dla troski chrześcijan o lasy było wystąpienie prawosławnego patriarchy Konstantynopola z okazji nadania mu doktoratu honorowego przez University of Amazonas in Manaus. Podczas tego wystąpienia Bartłomiej I stwierdził, że dla „zrozumienia równowagi [przyrody - RS] nie ma lepszego miejsca niż brazylijskie lasy deszczowe, nazywane «biblioteką życia» ze względu na wyjątkową różnorodność żyjących w nich gatunków zwierząt, drzew i roślin, ściśle i tajemniczo wzajemnie ze sobą powiązanych" (Web-o8). Patriarcha podkreślił także wkład w opiekę nad lasami ze strony żyjących w Amazonii społeczności indiańskich, które nie tylko chronią i opiekują się lasem, ale także przechowują rozległą wiedzę na jego temat (Web-o8).

Głos w sprawie ochrony lasów oraz zaprzestania nadmiernej i nieprzemyślanej deforestacji wielokrotnie zabierali też biskupi lub konferencje biskupów katolickich wielu krajów. Przykładem troski o lasy może być list, jaki skierowali do wiernych katoliccy biskupi z prowincji Alberta w Kanadzie. W liście tym zwrócili uwagę na związek pomiędzy deforestacją a dramatycznymi zmianami klimatu, jakie obserwujemy obecnie na całym świecie (Web-09). List o podobnej tematyce wystosowali także katoliccy biskupi Filipin, którzy wezwali władze do zahamowania wyrębu lasów. Wiernych zaś zachęcili do podejmowania stanowczych działań w celu ochrony dramatycznie kurczących się terenów leśnych (Catholic Bishops of the Philippines 1996).

O konieczności ochrony lasów mówi także papież Franciszek, który w encyklice Laudato si' wielokrotnie podejmował kwestię deforestacji. Szczególnie ważne wydaje się przywołanie przez papieża słów prawosławnego patriarchy Konstantynopola na temat moralnego wymiaru deforestacji (Franciszek papież 2015: nr 8). Ponadto papież w dokumencie tym wskazał na wielorakie konsekwencje stale zmniejszającej się lesistości Ziemi. Deforestacja - zdaniem papieża - potęguje zmiany klimatyczne, utratę bioróżnorodności, pustynnienie i zwiększa poziom zanieczyszczeń (Franciszek papież 2015: nr 24, 32, 38, 39, 195). Papież zwrócił się też do wszystkich ludzi dobrej woli z zachętą do rekultywacji lasów ze względu na ich pozytywny wpływ na stan środowiska, a co za tym idzie, na jakość życia ludzi, szczególnie zaś ludzi ubogich (Franciszek papież 2015: nr 58).

Szczególnie interesująca wydaje się międzyreligijna inicjatywa gromadząca przedstawicieli wszystkich światowych religii, którzy wspólnie zabrali głos w sprawie ochrony lasów deszczowych. Zebrani 
w Oslo w dniach 19-21 czerwca 2017 roku przedstawiciele religii pierwotnych, chrześcijaństwa, islamu, judaizmu, hinduizmu, buddyzmu i taoizmu wskazali na niepowtarzalną wartość lasów, które są niezbędnym warunkiem życia na Ziemi. Zwrócili też uwagę, że nieograniczona konsumpcja, nieodpowiedzialne systemy ekonomiczne i styl życia w bogatych krajach Północy prowadzą do szybkiej degradacji lasów deszczowych, zaś bez tych lasów wszystkich nas czeka zagłada. Liderzy religijni zwrócili się z apelem do swoich współwyznawców i ludzi dobrej woli na całym świecie o podejmowanie wspólnych inicjatyw na rzecz ochrony lasów. Zadeklarowali też powołanie do życia międzyreligijnego sojuszu w celu zapobiegania dalszej deforestacji (Web-10).

Oprócz różnych form ochrony istniejących lasów, jak choćby troska o święte gaje, czy wywieranie presji na rządy narodowe i organizacje międzynarodowe w celu zwiększenia aktywności na polu ochrony ekosystemów leśnych, instytucje religijne i organizacje ekologiczne o religijnej proweniencji podejmują liczne próby zalesiania terenów od dawna nie porastanych przez lasy. Inicjatywy tego typu obserwuje się w wielu tradycjach religijnych.

Dobrym przykładem prośrodowiskowej aktywności na rzecz lasów jest działalność hinduistycznej organizacji o nazwie Swadhyaya Movement. Począwszy od roku 1979 organizacja ta podejmuje liczne inicjatywy ekologiczne. Obecnie działa ona w wielu krajach Azji, Ameryki Północnej, Europy i Afryki, a także w Australii i na Karaibach. Celem tej organizacji jest otaczanie opieką ludzi, zwierząt, drzew, ziemi i całego wszechświata (Jain 2011: 17-19). Ruch Swadhyaya wypracował oryginalną metodę określaną jako prayog. Zasadniczym celem prayog'ów jest wzbudzenie u członków Swadhyaya respektu dla siebie i ludzkiej godności jednostek. Prayogi przyjmują formę projektów realizowanych przez poszczególne oddziały Swadhyaya, a wiele spośród nich polega na tworzeniu „drzewnych świątyń”, które są współczesnym odpowiednikiem świętych gajów. Członkowie tej organizacji zagospodarowują kilkunastohektarowe nieużytki - budują na nich studnie i systemy irygacyjne, rekultywują glebę oraz sadzą drzewa owocowe. Po zakończeniu prac Swadhyaya biorą na siebie stały obowiązek troski o drzewne świątynie, a produkty tam wyprodukowane przekazuja najuboższym (Sadowski 2013: 14-15).

Inną hinduistyczną inicjatywą na rzecz zalesiania jest akcja przeprowadzona przez Appiko Movement we współpracy z Ministerstwem Leśnictwa Indii w latach 1984-1985, w ramach której w regionie Sirsi posadzono ok. 1,2 mln drzew. Dzięki tego typu akcjom przeprowadzonym przez ekologiczne organizacje hinduistyczne posadzono w Indiach wiele milionów drzew (Jain 2011: 38).

Na uwagę zasługuje także działalność różnych organizacji ekologicznych nawiązujących do tradycji judaistycznej. Z okazji święta Tu B'Shevat określanego jako Nowy Rok Drzew na początku izraelskiej wiosny dzieci sadzą tysiące drzew. Ma to miejsce zarówno w Izraelu, jak i w wielu innych krajach świata, gdzie żydowskie społeczności aktywnie angażują się na rzecz środowiska (Sadowski 2013: 19-20).

Wiele projektów mających na celu nasadzenia lasów podejmują także organizacje chrześcijańskie. Ze względu na obecność tej religii niemal we wszystkich zakątkach świata wielość i różnorodność tych inicjatyw jest imponująca. Dla zilustrowania skali tych działań niech posłuży kilka przykładów. Godną zauważenia jest zrealizowana z sukcesem inicjatywa Christian Fellowship Church na Wyspach Salomona. Tam, gdzie wcześniej rządowi, międzynarodowym korporacjom ani lokalnym społecznościom nie udawało się przeprowadzić skutecznej akcji ponownego zalesienia, przedstawiciele tej chrześcijańskiej wspólnoty odnieśli spektakularny sukces. W wyniku przeprowadzonej akcji obsadzono drzewami znaczne tereny, przeprowadzono odpowiednie szkolenia oraz wskazano korzyści finansowe wynikające z przeprowadzonych nasadzeń. Uczestnicy tego projektu pytani o powody 
zaangażowania w sadzenie drzew aż w 54\% stwierdzili, że zasadniczym powodem była zachęta ze strony Kościoła (Racelis, Aswani 2011).

Inną interesującą chrześcijańską inicjatywą na rzecz zalesiania jest Reforestation Project prowadzony przez organizację o nazwie WorldRenew założoną przez Christian Reformed Church. WorldRenew działa w ponad 30 krajach, realizując różnego typu projekty na rzecz ubogich i środowiska. Reforestation Project ma na celu powiększenie lesistości, szczególnie w krajach rozwijających się. Inicjatorzy projektu są bowiem przekonani, że lasy pozytywnie wpływają na jakość gleby, która stwarza dobre warunki do uprawy żywności, zwiększa plony i dochody. Ponowne zalesianie zmniejsza skutki klęsk żywiołowych i lawin błotnych, które często występują na terenach górzystych, na których wycięto znaczne połacie lasu (Web-11). Kolejną godną zauważenia chrześcijańską inicjatywą na rzecz zalesiania jest Beer-Sheba Project. W ramach tej inicjatywy realizowany jest zintegrowany program składający się z modułu edukacyjnego, obejmującego całoroczny kurs na temat rolnictwa i Biblii oraz modułu szkoleniowego w zakresie rolnictwa małoobszarowego i leśnictwa oraz ich wpływu na lokalny ekosystem. Projekt ten został zainicjowany w roku 2002 przez organizacje chrześcijańskie w celu wsparcia młodych rolników w Senegalu (Web-12).

Bardzo interesującą inicjatywą zalesiania jest międzyreligijny Eden Reforestation Project. Od roku 2004, gdy projekt został zainaugurowany, zasadzono już ponad 196 mln drzew i stworzono wiele miejsc pracy, które liczone w roboczo-dniówkach osiągnęły liczbę niemal $2 \mathrm{mln}$. Projekt ten odniósł wielki sukces na Madagaskarze i Haiti oraz w Etiopii i Peru. Celem projektu jest nie tylko poprawa warunków środowiskowych poprzez zwiększanie lesistości danego obszaru, ale także poprawa warunków ekonomicznych lokalnych społeczności, które dzięki pracy przy nasadzeniach oraz trosce o zasadzone lasy zyskują miejsca pracy i środki niezbędne do życia. Eden Reforestation Project stawia sobie za cel by od roku 2020 móc każdego roku zasadzić minimum 100 mln drzew oraz stworzyć dziesiątki tysięcy miejsc pracy (Web-13).

Inną ważną inicjatywą religijną na rzecz poprawy stanu lasów było zwołanie w sierpniu 2007 w Visby w Szwecji spotkania pod hasłem Faiths and Forests. Na spotkaniu tym uzgodniono, że wszystkie instytucje religijne reprezentowane na spotkaniu, które są w posiadaniu lasów oraz instytucje, które mają istotny wpływ na innych właścicieli lasów, podejmą działania w celu zrównoważonego zarządzania tymi obszarami. Postanowiono, że do roku 2014 miliony hektarów lasów, które są w zarządzie instytucji religijnych, będą zarządzane w sposób przyjazny środowisku, korzystny społecznie i uzasadniony ekonomicznie. Podczas spotkania w Visby zainicjowano także powstanie Religious Forest Sites, który będzie koordynował religijne inicjatywy na rzecz ochrony ekosystemów leśnych (Web-14).

Religie wpływają korzystnie na lasy także ze względu na religijne motywacje swych wyznawców w odniesieniu do lasów. Efekty odmiennych motywacji ludzi wierzących widać po skuteczności podejmowanych przez nich akcji nasadzeń lasów. Z badań zaprezentowanych przez Pankaja Jaina wynika, że skuteczność religijnych zalesień jest znacznie wyższa niż typowych nasadzeń prowadzonych przez instytucje rządowe lub wyspecjalizowane firmy. Jain przywołuje dane przedstawione przez agendę ONZ Food and Agriculture, według której w latach 8o. XX wieku tylko ok. 66\% drzew posadzonych $w$ ramach działań rządowych przyjęło się, podczas gdy odsetek ten w przypadku nasadzeń realizowanych przez organizacje religijne jest znacznie wyższy, w niektórych przypadkach sięga nawet 100\% (Jain 2011: 36).

\section{Zakończenie}

Współczesne analizy kryzysu ekologicznego ujawniają niezwykłą złożoność tego zjawiska. Prowadzi to do wniosku, że nie da się 
znaleźć adekwatnego rozwiązania tego problemu, odwołując się do jednej lub nawet kilku dyscyplin wiedzy. Niezbędne jest poszukiwanie możliwie najszerszej płaszczyzny porozumienia, w której wezmą udział przedstawiciele wielu dyscyplin naukowych, a także politycy, reprezentanci świata sztuki, organizacji pozarządowych, a nawet przywódcy religijni. Tylko stworzenie takiego ogólnoświatowego porozumienia daje nadzieję na znalezienie dróg rozwiązania obecnego kryzysu oraz na wdrożenie konkretnych działań, które będą zarówno powszechnie akceptowane społecznie, jak i przyczynią się do skutecznej poprawy kondycji ziemskiego ekosystemu.

Wydaje się, że zły stan przyrody jest konsekwencją postępującej dominacji kultury nad naturą. Stopniowe nasilanie się tego zjawiska obserwujemy począwszy od nowożytności. Obecnie zaś osiągnęło ono swe apogeum w postaci niemal całkowitego zapanowania człowieka nad przyrodą, która zdana jest już niemal zupełnie na jego łaskę.

Remedium na współczesną chorobę przyrody zdominowanej przez kulturę nie może być jednak prosty powrót do dominacji świata przyrody nad światem kultury. Rozwiązanie takie jest bowiem nierealistyczne i niemożliwe do zaakceptowania dla ludzkości liczącej kilka miliardów osób. Wydaje się, że jedynym realistycznym rozwiązaniem kryzysu ekologicznego jest zbudowanie proporcjonalnej równowagi pomiędzy światem przyrody i światem kultury. Taka równowaga powinna zapewnić realizację potrzeb człowieka na rozsądnym poziomie przy jednoczesnym uwzględnieniu koniecznych potrzeb i realnych możliwości przyrody. Tylko tak budowana wzajemna relacja świata kultury i świata natury może doprowadzić do ich mutualistycznego związku, w którym obie strony będą jego rzeczywistymi beneficjentami. Pozwoli to stworzyć podstawy trwałej i stabilnej przyszłości świata kultury mądrze i odpowiedzialnie osadzonego w świecie natury.

\section{Bibliografia}

Arystoteles. 2006. Polityka. Warszawa: PWN.

Bonenberg M.M. 200o. Aksjologiczne problemy ekologii. W: Poznanie i doznanie. Eseje $z$ estetyki ekologii, red. M. Gołaszewska, 32-51.Kraków: Universitas.

Boucher K-L. 2011. "Collaboration for Conservation in Ankarana, Madagascar”. Totem: The University of Western Ontario Journal of Anthropology. 19. 59-66.

Catholic Bishops of the Philippines. 1996. What is Happening to Our Beautiful Land? W: And God Saw That It Was Good: Catholic Theology \& the Environment, red. D. Christiansen, Christiansen W. 309-318. Washington: United States Catholic Conference.

Foltz R.C. 2006. "Nature in Asian Traditions: The State of the Field". Worldviews: Environment CultureReligion. 10(1). 1-4.

Franciszek (papież). 2015. Encyklika Laudato si'. $W$ trosce o wspólny dom (24 maja 2015). Kraków: Wydawnictwo M.

Fritsch B. 1990. Mensch, Umwelt, Wissen. Evolutionsgeschichtliche Aspekte des Umweltproblems, Zurich-Sttudgart: Verlag der Fachvereine.

Gardner G.T. 2003.Engaging Religion in the Quest for a Sustainable World. W: State of the World 2003. A Worldwatch Institute Report on Progress Toward a Sustainable Society, red. G.T. Gardner et al., 152-177. New York: WW Norton \& Company. Gokhale Y. et al. 1988. Sacred woods, grasslands and water bodies as self-organized systems of conservation. W: Conserving the Sacred for Biodiversity Management, red. P.S. Ramakrishnan et al., 365-398. New Delhi: Oxford and IBH Publishing Co.

Hipokrates. 189o. O powietrzu, wodzie i miejscach. W: Dwie Księgi Hipokratesa Warszawa: Gebethner i Wolff.

Jain P. 2011. Dharma and Ecology of Hindu Communities Sustenance and Sustainability. Farnham: Ashgate.

Jonas H. 1995. Zasada odpowiedzialności. Etyka dla cywilizacji technologicznej. Kraków: Wydawnictwo Platan.

Łepko Z. 1995. Ekofilozofia jako praktyczna filozofia przyrody. W: Człowiek i środowisko. Humanistyka i ekologia, red. J. Dębowski, 37-43. Olsztyn: Wydawnictwo Wyższej Szkoły Pedagogicznej. 
Łepko Z. 2003. Antropologia kryzysu ekologicznego wświetle wspótczesnej literatury niemieckiej. Warszawa: Wydawnictwo UKSW.

Martin B.D., Schwab E. 2013. „Current usage of symbiosis and associated terminology", International Journal of Biology. 5(1). 32-45. doi:10.5539/ ijb.v5n1p32.

Meadows D.H. et al. 1973. Granice wzrostu, Warszawa: Państwowe Wydawnictwo Ekonomiczne. Meyer-Abich K.M. 1984. Wege zum Frieden mit der Natur. Praktishe Naturphilosophie für die Umweltpolitik, München-Wien: C. Hanser.

Meyer-Abich K.M. 1987. Naturphilosophie auf neuen Wegen. W: Über Natur: philosophische Beiträge zum Naturverständnis, red. O. Schwemmer, L. Schäfer, 63-73. Frankfurt am Main: Klostermanns.

Meyer-Abich K.M. 1988. Wissenschaft für die Zukunft: Holistisches Denken in ökologischer und gesellschaftlicher Verantwortung. München: C.H. Beck.

Moran E.F. 2006. People and Nature: An Introduction to Human Ecological Relations. Malden: Blackwell Publishing Professional.

Racelis A.E. Aswani S. 2011. "Hopes and Disenchantments of Religious Community Forestry in the Western Solomon Islands". Ecological and Environmental Anthropology. 6. 26-38.

Sadowski R.F. 2010. Religijne inspiracje przeciwdziałania kryzysowi ekologicznemu. W: Człowiek $i$ świat - wymiary odpowiedzialności, red. Wł. Tyburski, H. Ciążela, W. Dziarnowska, 77-86. Warszawa: Wydawnictwo Akademii Pedagogiki Specjalnej.

Sadowski R.F. 2012. „Potencjał religii w ochronie ekosystemów leśnych". Studia Ecologiae et Bioethicae. 10(4). 11-32.

Sadowski R.F. 2013. „Aktualizacja ekologicznego potencjału religii w ochronie ekosystemów leśnych", Studia Ecologiae et Bioethicae. 11(1). 7-27.

Sadowski R.F. 2015. Filozoficzny spór o rolę chrześcijaństwa w kwestii ekologicznej, Warszawa: TNFS.

Selmaj-Pomaska P. 2011. „Klausa Michaela Meyera-Abicha idea pokoju człowieka z przyrodą". Zeszyty Naukowe Towarzystwa Doktorantów UJ. Nauki Humanistyczne. Nr specjalny 3. 2. 345-355.

Simmons I.G. 1990. Changing the Face of the Earth. Culture, Environment, History, Cambridge: Blackwell Publishing.
Tucker M.E. 2003. Worldly Wonder: Religions Enter Their Ecological Phase, Chicago: Open Court.

Tukidydes. 1991. Wojna peloponeska, Wrocław-Warszawa-Kraków: Zakład Narodowy im. Ossolińskich.

Tyburski W. 2006. „Powstanie i rozwój filozofii ekologicznej". Problemy Ekorozwoju. 1. 7-15.

Wilson E.O. 2002. Afterword. W: Silent Sprint, red. R. Carson, 357-363. Boston-New York: Houghton Mifflin Company.

Yaakov G. 1997. Lost in Translation: Toward a Feminist Account of Chipko. W: Transitions, Environments, Translations: Feminisms in International Politics, red. J. W. Scott et al., 273-284. New York-London: Routledge.

(Web-o1) Chui-Ling Tam. Rewriting the fatwa at COP22. https://theieca.org/publications/blogs/ chui-ling-tam/2016/11/o9/rewriting-fatwa-cop22, dostęp: 31.03.2018.

(Web-02) Werntz K.M. Indonesia's fatwa shows religious duty can be a route to sustainable behavior. https://www.theguardian.com/sustainable-business/religion-environment-wildlife-trafficking-indonesia-fatwa-sustainable, dostęp: 31.03.2018. (Web-o3) Hiddleston S. Can "green fatwas" combat climate change? http://www.natureasia.com/en/ nmiddleeast/article/10.1038/nmiddleeast.2016.208, dostęp: 31.03.2018.

(Web-04) Dalai Lama. Hope for Tibet's Environment, przemówienie na konferencji pt. Endangered Tibet (Snlnn, Australia - 28.09.1996). https://www. dalailama.com/messages/environment/tibets-environment, dostęp: 31.03.2018.

(Web-05) Dharma Teachers and Sangha Members Worldwide. The Earth as Witness: International Dharma Teachers'Statement on Climate Change. https://oneearthsangha.org/articles/dharma-teachers-statement-on-climate-change, dostęp: 31.03.2018.

(Web-o6) Presbyterian Church (USA).Environment and Energy. http://www.pcusa.org/site_media/ media/uploads/washington/pdfs/policybrief.pdf, dostęp: 31.03.2018.

(Web-07) The United Methodist Church. Environmental Justice for a Sustainable Future. http:// main.umc-gbcs.org/resolutions/environmentaljustice-for-a-sustainable-future-1023-2008-bor, dostęp: 31.03.2018. 
(Web-o8) Bartłomiej I. Acceptance Speech for the Honorary Doctorate at the University of Amazonas in Manaus (14.07.2006). http://tnij.at/Bartlomiejolasach, dostęp: 31.03.2018.

(Web-09) Bishops of Alberta Province. Celebrate Life: Care for Creation (4.10.1998). http://www.wcr. ab.ca/bin/eco-lett.htm, dostęp: 10.11.20o8.

(Web-10) Interfaith Rainforest Initiative (Oslo, 19-21.06.2017), http://fore.yale.edu/files/Interfaith_Rainforest_Initiative_Statement.pdf, dostęp: 31.03.2018
(Web-11) WorldRenew, Living Justice, Loving Mercy, Serving Christ, https://worldrenew.net, dostęp: 3.04.2018.

(Web-12) The Beer-Sheba Project, http://beershebaproject.org, dostęp: 3.04.2018.

(Web-13) Eden Reforestation Projects, Plant trees, save lives, https://edenprojects.org, dostęp: 3.04.2018.

(Web-14) ARC, Millions of hectares of religious forest managed ecologically by 2014, http://www. arcworld.org/projects.asp?projectID=529, dostęp: 3.04.2018.

\title{
The importance of the humanities in shaping a realistic relationship between humans and nature
}

\begin{abstract}
Along with the deepening of the ecological crisis, our understanding of its nature is also increasing. While the analysis of its causes and effects, along with the development of a strategy to overcome it, was at first carried out solely by representatives of the natural and technical sciences, it has now been undertaken also by humanists, artists and cultural and religious leaders. The joining of humanists in this endeavour enables better recognition of the nature of the ecological crisis and consequently helps to develop a more adequate strategy to counteract its impact. Particularly noteworthy is the contribution of world religions in shaping a realistic relationship between humanity and nature. This article points to the increasing humanisation of the ecological reflection and offers examples of the commitment demonstrated by representatives of various religious traditions to the protection of forests
\end{abstract}

\section{Keywords}

humanist ecology, environmental philosophy, religion and ecology, land art, forest 